\title{
AQUEOUS LIQUID MEMBRANE PROCESS FOR RECOVERY OF BTX AROMATICS
}

\author{
I Dewa Gede Arsa Putrawan \\ Department of Chemical Engineering \\ Institut Teknologi Bandung \\ Jalan Ganesha 10 Bandung 40132, Indonesia \\ Email: idewa@che.itb.ac.id
}

\begin{abstract}
An aqueous liquid membrane process has been developed for extracting BTX aromatics in catalytic reformate. The process mainly involved a multistage liquid-membrane permeator and two distillation towers. Continuous stirred vessels were utilized as contactors for permeation. Aqueous solution of saponin and light oil were used as liquid membrane and receiving phase, respectively. The equations of material balance, permeation, and constrain have been solved to study the effects of operating variables on the product yield and BTX purity. BTX purity up to $95 \%$ and yield of $90 \%$ could be achieved. The larger the values of solvent-to-feed ratio, stirring rate, number of permeation stages, permeator reflux ratio, or permeator volume, the greater the energy requirement. The energy supplied to the process is mainly utilized to recover solvent. Solvent-to-feed ratio was found to be the most influential variable on energy demand. The purity of BTX aromatics increases as the permeator reflux ratio and solvent-to-feed ratio increase or the stirring rate, number of permeation stages, and permeator volume decrease. The opposite trends are observed for the yield of BTX aromatics. The raffinate obtained was found to be a good blendstock for clean motor gasoline.
\end{abstract}

Keywords: Liquid membrane, BTX Aromatic, Stirred vessel

\begin{abstract}
Abstrak
Proses membran cair akuatik telah dikembangkan untuk ekstraksi aromatik BTX dari reformat katalitik. Proses tersebut melibatkan permeator multitahap dan dua kolom distilasi sebagai alat utama. Tangki berpengaduk kontinyu digunakan sebagai alat kontak permeasi. Larutan saponin dalam air digunakan sebagai membran cair dan minyak ringan digunakan sebagai fasa penerima. Persamaan-persamaan neraca massa, permeasi dan kendala proses telah diselesaikan untuk mengkaji pengaruh berbagai variabel operasi terhadap perolehan produk dan kemurnian BTX. Kemurnian BTX hingga 95\% dan perolehan hingga 90\% dapat dicapai. Jika rasio pelarut-terhadap-umpan, laju pengadukan, jumlah tahap permeasi, rasio refluks permeator, atau volume permeator ditingkatkan, maka kebutuhan energi menjadi semakin besar. Energi yang dipasok ke dalam proses didominasi oleh pemulihan pelarut. Rasio pelarut-terhadap-umpan diketahui sebagai variabel yang paling berpengaruh terhadap kebutuhan energi. Kemurnian aromatik BTX semakin meningkat jika laju pengadukan, jumlah tahap permeasi, rasio refluks permeator, atau volume permeator dikurangi. Hal sebaliknya ditemukan untuk nilai perolehan aromatik BTX. Rafinat yang diperoleh diketahui sebagai bahan yang baik untuk gasolin motor ramah lingkungan.
\end{abstract}

Kata kunci: Membran cair, Aromatik BTX, Tangki berpengaduk 


\section{Introduction}

Catalytic reformate is the main source for BTX (benzene, toluene and xylenes) aromatics. Currently, solvent extraction with polar solvent is the traditional way for recovering BTX aromatics from catalytic reformate, and also from other sources. However, the process is energy consuming and generates waste of polar solvent. As energy is getting more expensive and environmental regulations become more stringent, better processes need to be developed.

Aqueous liquid membrane process has long been known to be a good alternative to solvent extraction because it needs lower capital cost, it has higher selectivity, it is less energy consuming, and it does not utilize polar solvent. Many attempts have been undertaken to study the application of aqueous liquid membrane since it was introduced four decades ago (Li, 1966). Most experiments were carried out in batch stirred vessels (Shah and Owens, 1972; Casamatta et al., 1978; Ihm et al., 1987; Chakraborty and Datta, 1996; Kato and Kawasaki, 1987; Garti and Kovacs, 1991; Sharma and Goswami, 1994; Ghosh et al., 1994; Kim et al., 1997; Krishna et al., 1987) although column type contactors have been considered (Jeong et al., 1987; Egashira, 1996). The feeds investigated covered synthetic mixtures as well as petroleum fractions, such as naphtha, kerosene, and LPG condensate. Permeation enhancement and membrane stability have also been examined.

Apart from the overwhelming work, however, no attention has been paid to design aqueous liquid membrane process causing its industrial application is still remote. It is the purpose of this research to design an aqueous liquid membrane process for separating aromatics from paraffins. The recovery of BTX aromatics from catalytic reformate is selected as a case study due to its widespread application. At first, a series of experiments were conducted to develop an empirical correlation for mass transfer coefficient. The equation is necessary for completing material and energy balances of the process developed. Secondly, a process flow will be developed. The material and energy balances of the process were completed and a series of simulation was performed to find optimum process conditions.

\section{Methodology}

\subsection{Process Description}

The schematic diagram of the process is illustrated in Figure 1. The process equipment mainly consists of a multistage liquidmembrane permeator and two distillation towers. Continuous stirred vessels are employed as contactors. In the actual process, each contactor is equipped with a settler to separate the $0 / \mathrm{W}$ emulsion from the extract leaving the contactor. However, to simplify the flow diagram, the settlers are not shown
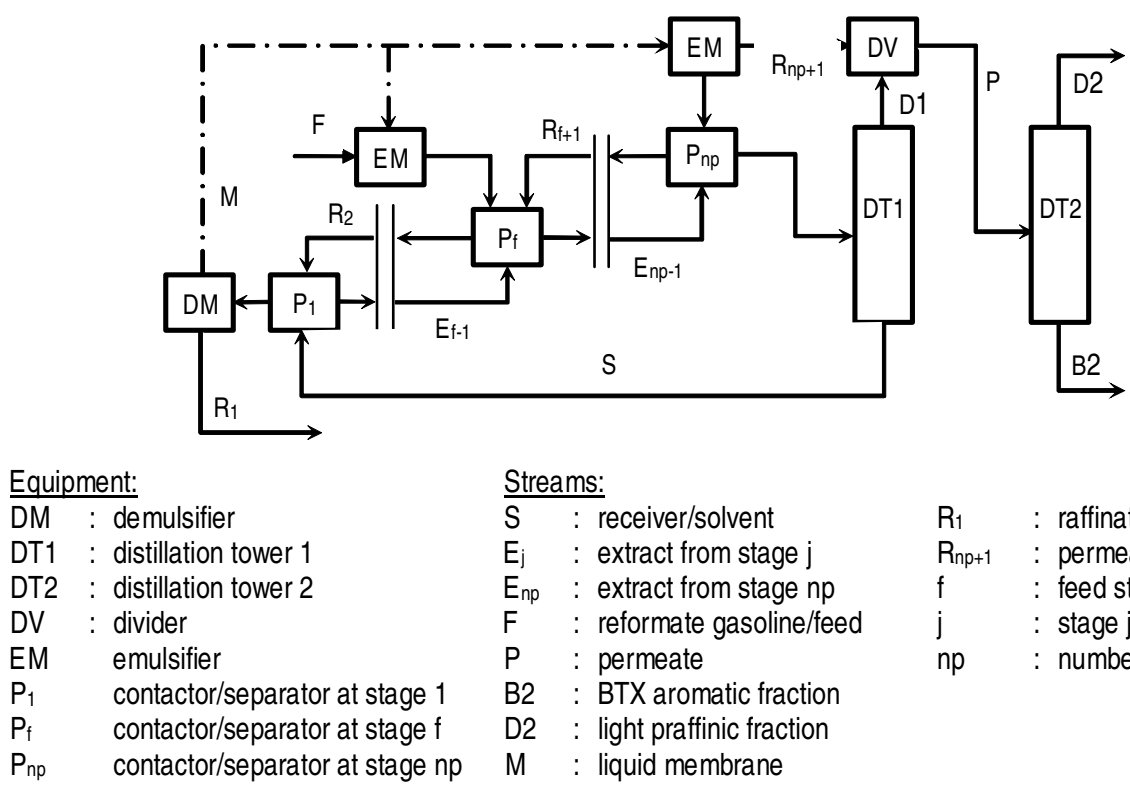

$$
\begin{aligned}
& \text { Streams: } \\
& S: \text { : receiver/solvent } \quad R_{1}: \text { raffinate from stage } 1 \\
& E_{j} \quad \text { : extract from stage } j \quad R_{n p+1} \quad \text { : permeator reflux } \\
& E_{n p}: \text { extract from stage } n p \quad f \quad \text { : feed stage } \\
& F \quad \text { : reformate gasoline/feed } j \quad \text { : stage j } \\
& \mathrm{P} \text { : permeate } \mathrm{np} \text { : number of stages } \\
& \text { B2 : BTX aromatic fraction } \\
& \text { D2 : light praffinic fraction } \\
& \text { M : liquid membrane }
\end{aligned}
$$

Figure 1. Flow diagram of aqueous liquid membrane process for recovery of BTX aromatics from catalytic reformate 
in Figure 1. For the permeator, aqueous solution of saponin is used as membrane solution and light oil is used as solvent.

The feed (F), catalytic reformate in this case, is emulsified in the membrane solution and sent into the permeator at an appropriate feed stage. In the permeator, the emulsion and extract phases are contacted countercurrently. The extract coming from the last permeation stage $\left(E_{n p}\right)$ is sent into the first tower (DT1) to obtain permeate and to recover receiver $(\mathrm{S})$. A part of the permeate is emulsified and returned to the permeator as reflux $\left(R_{n p+1}\right)$ in order to enrich the aromatics in the extract. The rest of permeate $(\mathrm{P})$ is treated by the second distillation tower (DT2) to separate BTX aromatic fraction from other heavier aromatic fraction. The emulsion from the first permeation stage is demulsified to obtain raffinate $\left(R_{1}\right)$ and to recover the membrane solution. The membrane solution and solvent are recycled. All towers operate at atmospheric pressure.

\subsection{Fundamental Equations}

The equations representing the above process can be derived from the material and heat balances of each unit. Only the equations for the permeator are given here. Figure 2 generalizes the flow in a typical permeation stage. The related equations can be written as:

- $\quad$ Component mass balance

$x_{i, j+1}^{R} R_{j+1}+x_{i, j-1}^{E} E_{j-1}+x_{F, i} F_{j}$

$=x_{i, j}^{R} R_{i, j}+x_{i, j}^{E} E_{i, j}$

$\mathrm{F}_{\mathrm{j}}=\mathrm{F}$ for $\mathrm{j}=\mathrm{f}, \mathrm{F}=0$ for $\mathrm{j} \neq \mathrm{f}$

- Permeation equation

$x_{i, j}^{E} E_{j}-x_{i, j-1}^{E} E_{j-1}$

$=P_{i} a_{j} V\left(x_{i, j}^{R}-x_{i, j}^{E}\right)$

- Constraints on mass fractions

$\sum_{i=1}^{c} x_{i, j}^{R}=1 ; \sum_{i=1}^{c} x_{i, j}^{E}=1$

In this case, $\mathrm{x}^{\mathrm{E}_{\mathrm{i}, \mathrm{j}}}$ and $\mathrm{x}_{\mathrm{i}, \mathrm{j}}$ are mass fractions of component $\mathrm{i}$ in extract and raffinate, respectively, leaving stage $j, E_{j}$ and $R_{j}$ are flow rates of extract and raffinate, respectively, leaving stage $j, F_{j}$ is flow rate of feed entering stage $j, P_{i}$ is overall permeation coefficient of component $\mathrm{i}, \mathrm{a}$ is specific contact area, $\mathrm{V}$ is volume of vessel, c is number of components, and $\mathrm{f}$ is feed stage.

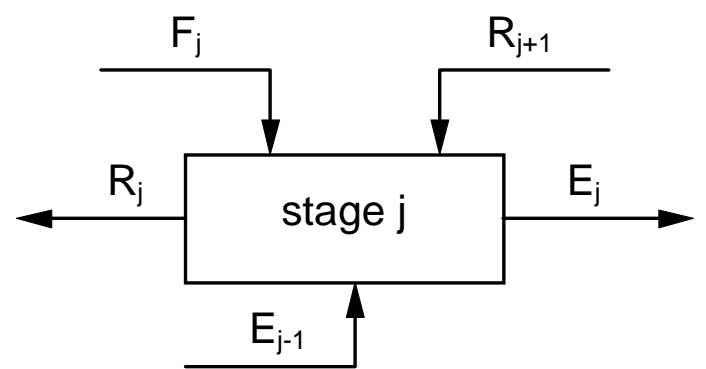

Figure 2. One typical permeation stage

By defining the following dimensionless variables:

$R_{j}^{*}=R_{j} / R_{n p+1}$

$R_{i, j}^{*}=R_{i, j} / R_{n p+1}$,

$V_{i, j}^{*}=V a_{j} D_{i} H_{i} /\left(F d_{o}^{2}\right)$,

$E_{j}^{*}=E_{j} / S$,

$E_{i, j}^{*}=E_{i, j} / S$,

$\phi_{R}=R_{n p+1} / F$,

$\phi_{S}=S / F$,

where $R_{n p+1}, S$, and $F$ are flow rates of permeator reflux, solvent, feed, respectively, $D_{i}$ and $H_{i}$ are diffusivity and partition coefficient, respectively, of component $i$, and $\mathrm{d}_{\mathrm{o}}$ is diameter of inner oil droplet in $0 / \mathrm{W}$ emulsion, the fundamental equations can be rewritten as follows:

- Component mass balance

$\phi_{R}\left(R_{i, j+1}^{*}-R_{i, j}^{*}\right)+\phi_{E}\left(E_{i, j-1}^{*}-E_{i, j}^{*}\right)$;

$+x_{i, F} \cdot \phi_{F}=0$

$\phi_{\mathrm{F}}=1$ for $\mathrm{j}=\mathrm{f}, \phi_{\mathrm{F}}=0$ for $\mathrm{j} \neq \mathrm{f}$

- Permeation equation

$\phi_{E}\left(E_{i, j}^{*}-E_{i, j-1}^{*}\right)-P_{i}^{*} V_{i, j}^{*}$

$\left(R_{i, j}^{*} / R_{j}^{*}-E_{i, j}^{*} / E_{j}^{*}\right)=0$

- Constraints on mass fractions

$R_{j}^{*}=\sum_{i=1}^{c} R_{i, j}^{*}, E_{j}^{*}=\sum_{i=1}^{c} E_{i, j}^{*}$

A computer program, applying the Newton-Raphson numerical method, was written to solve the above equations. Separate program was also written to solve the distillation equations. To compute the whole recovery process, the permeation and the distillation programs were run alternately. The process conditions are summarized in Table 1 , the underlined values are standard 
values. Diffusivities of components were calculated from Wilke and Chang's correlation (Wilke and Chang, 1955) and the solubility data from McAuliffe (1966) was adopted. The feed composition is shown in Table 2. The Light oil was treated as n-hexadecane. The feed stages of the distillation towers were determined by minimizing their corresponding reboiler duties. The feed stage of the permeator was determined in such a

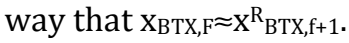

\section{Results and Discussion}

\subsection{Number of distillation stages}

For each distillation tower, the number of equilibrium stages $\left(\mathrm{n}_{\mathrm{DT}}\right)$ which gives a minimum energy requirement was investigated. It was found that the reboiler duty of DT1 decrease remarkably at number of stages lower than 9. On the other hand, the reboiler duty of DT2 is almost constant at number of stages arround 20. For the subsequent calculation, therefore, the number of stages of DT1 and DT2 were set equal to 9 and 20 , respectively.

\subsection{Effects of permeator variables}

Under the range of condition shown in Table 1, the effects of permeator variables on the total energy requirement, purity and yield of BTX aromatics have been examined. The total energy requirement is approximated as the sum of the reboiler duties of the distillation towers:
$\mathrm{Q}_{\mathrm{B}, \mathrm{t}}=\mathrm{Q}_{\mathrm{B}, \mathrm{DT} 1}+\mathrm{Q}_{\mathrm{B}, \mathrm{DT} 2}$

and the yield of component $i$ is calculated as

$Y_{i}=\left(x_{i, B 2} B 2\right) /\left(x_{i, F} F\right)$

where B2 is the flow rate of BTX stream. In this case, the permeator variables studied were solvent-to-feed flow rate ratio $(S / F)$, stirring rate $(N)$, number of permeation stages $\left(n_{P}\right)$, permeator reflux ratio $\left(r_{P}\right)$, and stage volume $(V)$. The permeator reflux ratio was defined as:

$\mathrm{r}_{\mathrm{P}}=\mathrm{R}_{\mathrm{np}+1} / \mathrm{P}$

where $R_{n p+1}$ and $P$ are the flow rate of permeator reflux and that of permeate sent into the second distillation tower, respectively.

Figure 3 and Figure 4 show the effects of permeator variables on the purity and yield of BTX and energy demand of distillation. In general, under the condition studied here, the process developed demonstrates good performances. BTX purity of $95 \%$ and yield of $90 \%$ could be achieved. The larger the values of solvent-to-feed flow rate ratio, stirring rate, number of permeation stages, permeator reflux ratio, or permeator volume, the greater the energy requirement. It is due the increase in capacity of distillation towers when the values of these variables are increased.

Table 1. Calculation Condition

\begin{tabular}{|c|c|c|c|c|c|}
\hline \multicolumn{2}{|c|}{ Variable } & Value & & & Value \\
\hline \multicolumn{2}{|l|}{$\mathrm{F}\left[\mathrm{kg} \cdot \mathrm{h}^{-1}\right]$} & 500 & $\mathrm{Xs,D1}[$ & & 0,0001 \\
\hline \multicolumn{2}{|c|}{$\mathrm{CSAP}_{\mathrm{SAg}}\left[\mathrm{kg} \cdot \mathrm{m}^{-3} \mathrm{aq}.\right]$} & 3 & $\mathrm{XS}, \mathrm{B} 1[$ & & 0.9999 \\
\hline \multicolumn{2}{|l|}{ nDT1 $[-]$} & 8 & $\mathrm{XHx}, \mathrm{D} 2$ & $\mathrm{PP}[-]$ & 0.9600 \\
\hline \multicolumn{2}{|l|}{$\mathrm{n}_{\mathrm{DT} 2}[-]$} & 20 & $\mathrm{X}_{\mathrm{B}, \mathrm{B} 2 \mathrm{E}}$ & $P[-]$ & 0.9600 \\
\hline \multicolumn{6}{|c|}{ Varied variables } \\
\hline$S / F[-]$ & \multicolumn{2}{|c|}{2 to 6} & $\mathrm{r}_{\mathrm{P}}[-]$ & \multicolumn{2}{|c|}{0 to 10} \\
\hline $\mathrm{N}\left[\mathrm{jam}^{-1}\right]$ & \multicolumn{2}{|c|}{$\begin{array}{l}1000 \text { to } 2600 \\
1 \text { to } 15\end{array}$} & $\mathrm{~V}\left[\mathrm{~m}^{3}\right]$ & \multicolumn{2}{|c|}{0.1 to 2.0} \\
\hline
\end{tabular}

Table 2. Feed Composition

\begin{tabular}{|c|c|c|c|}
\hline \multicolumn{2}{|c|}{ Aromatic } & \multicolumn{2}{|c|}{ Parafin } \\
\hline Benzene & 0.0679 & n-Butane & 0.0264 \\
\hline Toluene & 0.2370 & n-Pentane & 0.0372 \\
\hline Xylene & 0.2543 & 1-Methylbutane & 0.0534 \\
\hline Etylbenzene & 0.0518 & n-Hexane & 0.0363 \\
\hline \multirow[t]{3}{*}{ Trimethylbenzene } & 0.0981 & 2-Methylpentane & 0.0410 \\
\hline & & 3-Methylpentane & 0.0314 \\
\hline & & n-Heptane & 0.0652 \\
\hline Total & 0.7091 & Total & 0.2909 \\
\hline
\end{tabular}



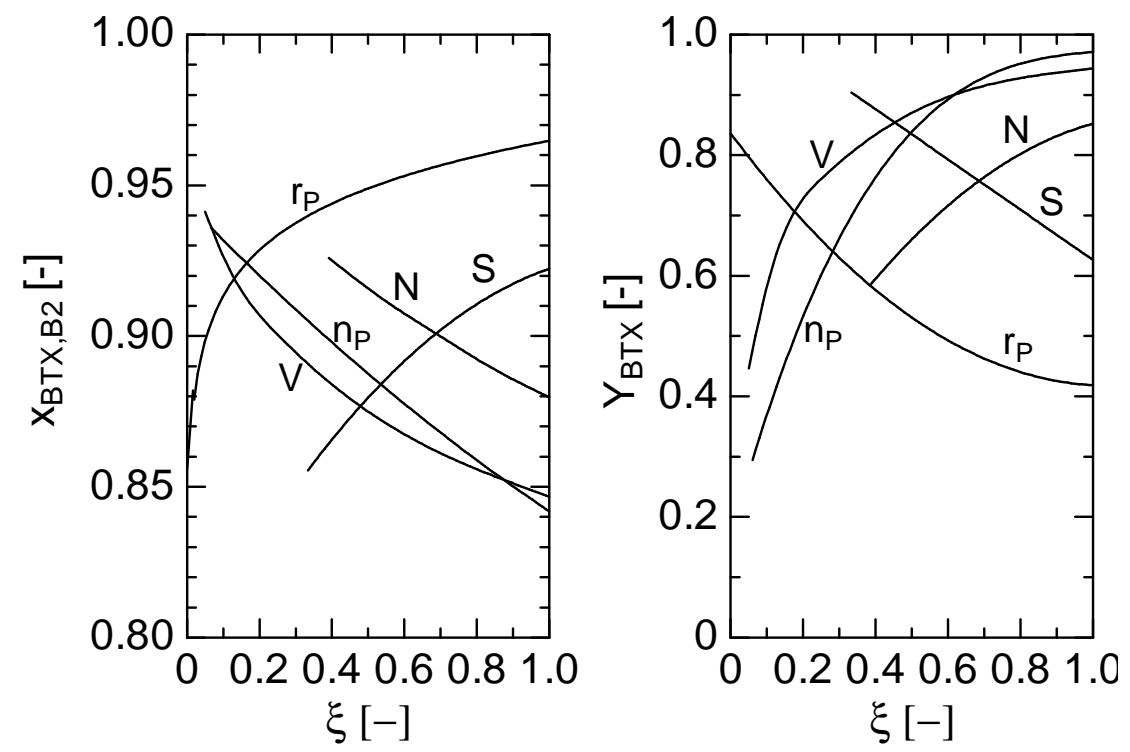

Figure 3. Effects of permeator variables on BTX purity and yield
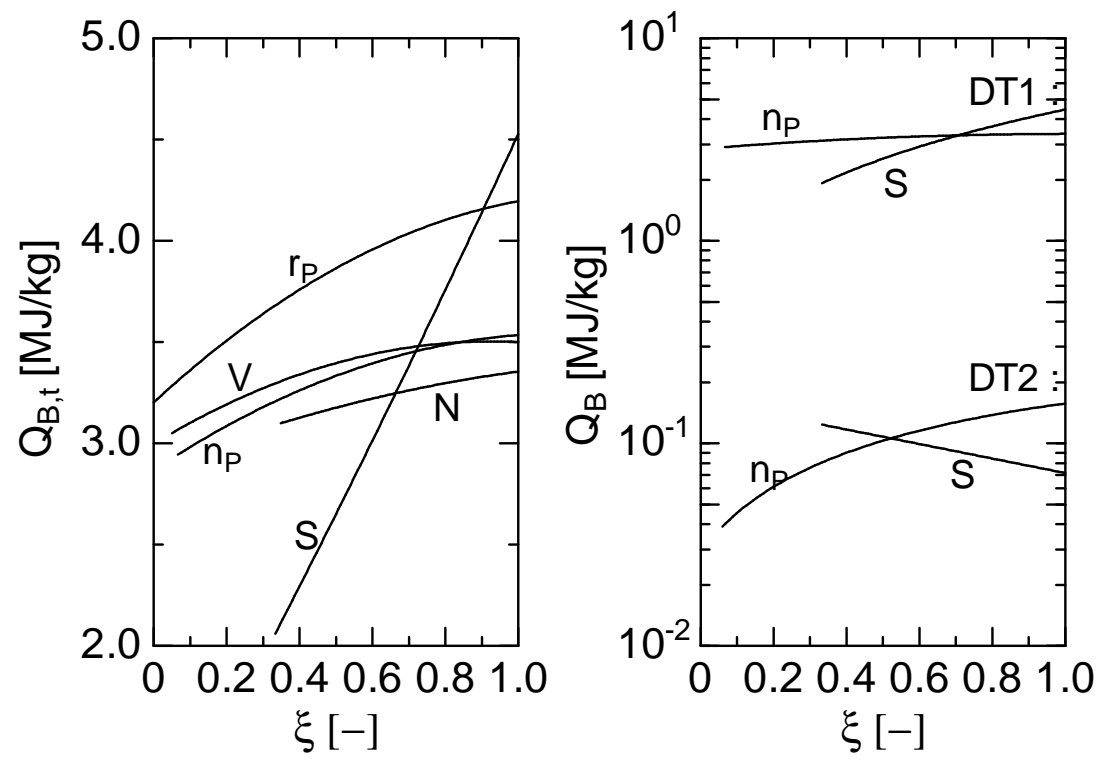

Figure 4. Effects of permeator variables on energy demand

(product) increase as the permeator reflux ratio and solvent-to-feed ratio increase or the stirring rate, number of permeation stages, and permeator volume decrease. The opposite Among the variables studied, solvent-to-feed ratio has the most influence on the reboiler duty. The same phenomenon was also found by Egashira (1996). The purity of BTX aromatics stream trends are observed for the yield of BTX aromatics. This means that there is a trade-off between yield and purity in selecting the optimum operating condition of permeation. There is also a trade-off between energy demand and yield in fixing permeator reflux ratio and solvent-to-feed ratio and between energy demand and purity in fixing permeator stirring rate, number of permeation stages, and permeator volume. Thus, the optimization of permeation condition seems to be very complicated. In practice, however, the optimization will be simplified by the main purpose of the process. If the yield of BTX aromatics is favored, for example, the process is recommended to operate at high stirring rate, number of permeation stages, and permeator volume, and at low permeator reflux ratio and solventto-feed ratio.

On the right-hand-side of Figure 4 are the effects of $S / F, n_{P}$, and $r_{P}$ on the energy for 
recovering solvent and that for concentrating BTX aromatics. Apparently, the first tower consumes considerably more energy than the second tower since the feed of the first tower is much greater than that of the second tower, it could be up to $90 \%$ of the total energy. It means that the energy demand is mainly controlled by solvent recovery. Improvement on receiver recovery unit, therefore, will result in a great saving on operating cost.

\subsection{Heat integration}

Heat integration has been considered to reduce energy demand. The first insight was to consider heat integration between distillation towers; that is between the condenser of DT1 and the reboiler of DT2 or the condenser of DT2 and the reboiler of DT1. In Table 3 is presented a typical calculation result in which the temperatures of distillation towers are included. It is clearly shown that temperature differences prohibit the integration of distillation towers without changing distillation pressure. The integration between the condenser of DT2 and the reboiler of DT1 seems to be not a good alternative since the difference between the bottom temperature of DT1 and the top temperature of DT2 is large. Increasing the pressure of DT1 up to $1.55 \mathrm{~atm}$, allows us to match the condenser of DT1 and the reboiler of DT2 with a temperature difference of $10^{\circ} \mathrm{C}$ so that the reboiler duty of DT2 could be fulfilled. However, as mentioned earlier, the reboiler duty of DT2 is almost neglected compared to the total energy demand. Thus, this second alternative is also not necessary.Another alternative in utilizing the heat content of the hot receiver stream $(\mathrm{S})$ is for demulsifying since heating is an alternative for breaking emulsion (Kato and Kawasaki, 1987). Thermal demulsification of $0 / W$ emulsion by using the receiver from the bottom of DT1 is recommended to reduce energy demand.

\subsection{Raffinate as a Clean Gasoline Blendstock}

The raffinate is basically dearomatized catalytic reformate. A typical composition of raffinate is given in Table 3 . It can be seen that the feed, catalytic reformate, experiences aromatic reduction, especially the toxic benzene, significantly after passing the aqueous emulsion liquid membrane permeator. It is due to the significant differences in permeation rates between aromatic and paraffinic fractions (Li, 1966; Kato and Kawasaki, 1987; Kim et al., 1997). The raffinate, therefore, is thought to be a clean motor gasoline blendstock Blending the raffinate obtained here, a fluid catalytic cracking gasoline (30\%-vol aromatics and

Table 3. Typical calculation result

\begin{tabular}{|c|c|c|c|c|c|}
\hline & \multicolumn{4}{|c|}{ Flow (kg.h-1) } & \\
\hline & $\mathbf{F}$ & $\mathbf{R}_{1}$ & $\mathbf{P}$ & B2 & \\
\hline & 500 & 251 & 249 & 235 & \\
\hline Composition & & & & & Yield \\
\hline Aromatic & 0.7091 & 0.4736 & 0.9461 & 0.9984 & 0.66 \\
\hline Benzene & 0.0679 & 0.0010 & 0.1353 & 0.1379 & 0.99 \\
\hline Toluene & 0.2370 & 0.0453 & 0.4301 & 0.4572 & 0.90 \\
\hline Xylenes & 0.2543 & 0.2209 & 0.2877 & 0.3054 & 0.56 \\
\hline Etylbenzene & 0.0518 & 0.0507 & 0.0528 & 0.0560 & 0.51 \\
\hline Trimetilbenzene & 0.0981 & 0.1557 & 0.0402 & 0.0420 & 0.20 \\
\hline Paraffinic & 0.2909 & 0.5264 & 0.0539 & 0.0016 & 0.09 \\
\hline n-Butane & 0.0264 & 0.0398 & 0.0129 & 0.0000 & 0.24 \\
\hline n-Pentane & 0.0372 & 0.0634 & 0.0108 & 0.0000 & 0.14 \\
\hline 1-Methylbutane & 0.0534 & 0.0860 & 0.0205 & 0.0000 & 0.19 \\
\hline n-Hexane & 0.0363 & 0.0702 & 0.0022 & 0.0001 & 0.03 \\
\hline 2-Methylpentane & 0.0410 & 0.0780 & 0.0037 & 0.0000 & 0.04 \\
\hline 3-Methylpentane & 0.0314 & 0.0600 & 0.0027 & 0.0000 & 0.04 \\
\hline n-Heptane & 0.0652 & 0.1290 & 0.0010 & 0.0015 & 0.01 \\
\hline Distillation & & DT1 & DT2 & & \\
\hline Number of stages & & 9 & 20 & & \\
\hline Reflux ratio & & 0.1 & 5.4 & & \\
\hline Top temp. & & 87 & 39 & ${ }^{\circ} \mathrm{C}$ & \\
\hline Bottom temp. & & 287 & 111 & ${ }^{\circ} \mathrm{C}$ & \\
\hline Reboiler duty & & 1,585 & 45 & MJ & \\
\hline
\end{tabular}


$1 \%$-vol benzene), and another blendstock (containing no aromatic and benzene) with blending ratios of $0.35,0.35$, and 0.3 , respectively, produces a motor gasoline having 24\%-vol aromatics and $0.4 \%$-vol benzene. The aromatic and benzene contentsof this blending product comply with the Clean Air Act 1990 (aromatic and benzene contents are lower than 25\%-vol and 1\%, respectively).

\section{Conclusion}

An aqueous liquid membrane process for recovery of BTX aromatics has been developed and the related material balances have also been completed. Moreover, the effects of permeator variables on the energy demand of the process were studied and process heat integration was considered as well. The process developed demonstrates good performances. BTX purity of $95 \%$ and yield of $90 \%$ could be achieved. The larger the values of solvent-to-feed flow rate ratio, stirring rate, number of permeation stages, permeator reflux ratio, or permeator volume, the greater the energy requirement. The energy demand of the process mainly utilized to recover solvent. Solvent-to-feed ratio was found to be the most influential variable on energy demand. The purity of BTX aromatics stream (product) increase as the permeator reflux ratio and solvent-to-feed ratio increase or the stirring rate, number of permeation stages, and permeator volume decrease. The opposite trends are observed for the yield of BTX aromatics. The raffinate obtained was found to be a good blendstock for clean motor gasoline.

\section{Acknowledgment}

Author deeply appreciates the Asahi Glass Foundation for funding this research.

\section{References}

Casamatta, G.; Bouchez, D.; Angelino, H., Liquid membrane separation: Modelling and development of a continuous counter-current pilot scale contactor, Chemical Engineering Science, 1978, 33(2), 145-152.

Chakraborty, R.; Datta, S., Determination of membrane thickness for emulsion liquid membrane macrodrops: A new approach, Journal of Membrane Science, 1996, 115(2), 129-132.
Egashira, R., Separation of Hydrocarbons in Reformate Gasoline by Emulsion Liquid Membran, Ph.D. Dissertation, Tokyo Institute of Technology, December 1996.

Garti, N.; Kovacs, A., Facilitated emulsion liquid membrane separation of complex hydrocarbon mixtures, Journal of Membrane Science, 1991, 56(3), 239-246.

Ghosh, A. C.; Patil, G. S.; Dutta, N. N., Liquid membrane permeation of aromatic hydrocarbons in LPG condensate, Fuel Processing Technology, 1994, 38(1), 17-30.

Ihm, S. K.; Jeong, Y. H.; Won, Y. S., Experimental investigation of the oil/water/oil liquid-membrane separation of toluene and n-heptane: I. Batch test of a mixer-settler, Journal of Membrane Science, 1987, 32, 31-46.

Jeong, Y. H.; Ihm, S. K.; Won, Y. S., Experimental investigation of the oil/water/oil liquid-membrane separation of toluene and n-heptane: II. Continuous test of a countercurrent permeator, Journal of Membrane Science, 1987, 32(1), 47-57.

Kato, S.; Kawasaki, J., Enhanced permeation of hydrocarbon through liquid membranes by lipophilic surfactants, Journal of Chemical Engineering of Japan, 1987, 20(2), 140-145.

Kim, S. J.; Kim, S. C.; Kawasaki, J., Separation of hydrocarbons by liquid surfactant membrane with a batch stirred vessel, Separation Science and Technology, 1997, 32(7), 1209-1221.

Krishna, R; Goswami, A. N.; Sharma, A. Effect of emulsion breakage on selectivity in the separation of hydrocarbon mixtures using aqueous surfactant membranes, Journal of Membrane Science, 1987, 34(2), 141-154.

Li, N. N., Separating hydrocarbons with liquid membrane. U.S. Patent 3,410,794, 14 Mar 1966.

McAuliffe, C., Solubility in water of paraffin, cycloparaffin, olefin, acetylene, cycloolefin, and aromatic hydrocarbons, The Journal of Physical Chemistry, 1966, 70(4), 1267-1275.

Shah, N. D.; Owens, T. C., Separation of benzene and hexane with liquid membrane technique, Industrial \& Engineering Chemistry 
Product Research and Development, 1972, 11(1), 58-63.

Sharma, S. K.; Goswami, A. N., Dearomatisation of a refinery kerosene by liquid surfactant membranes - prediction of extraction rates,
Journal of Membrane Science, 1994, 88(1), 6976.

Wilke, C. R.; Chang, P., Correlation of diffusion coefficients in dilute solutions, AIChE Journal, 1955, 1(2), 264-270. 